\title{
Lithospheric scale 3D thermal model of the Alpine- Pannonian transition zone
}

\author{
L. Lenkey ${ }^{1}$ (D) D. Raáb ${ }^{1}$ G. Goetzl ${ }^{2}$ - A. Lapanje L $^{3}$ \\ A. Nádor ${ }^{4}$ D. Rajver ${ }^{3}$ Á. Rotár-Szalkai ${ }^{4} \cdot$ J. Svasta $^{5}$. \\ F. Zekiri ${ }^{2}$
}

Received: 26 August 2016/Accepted: 20 January 2017/Published online: 4 February 2017

(C) Akadémiai Kiadó 2017

\begin{abstract}
In this paper we present the results of 3D conductive thermal modeling of the Alpine-Pannonian transition zone. The study area comprises the Vienna, Danube, Styrian and Mura-Zala basins, surrounded by the Eastern Alps, the Western Carpathians and Transdanubian Range. The model consists of three layers: Tertiary sediments, the underlying crust and lithospheric mantle. The crust and mantle were homogenous with constant thermal properties. Heat production in the sediments and crust was $1 \mu \mathrm{W} / \mathrm{m}^{3}$. The thermal conductivity of sediments varied horizontally and vertically and based on laboratory measurements. We tested two scenarios: a steady-state and a time-dependent case. The conductive heat transport equation was solved by finite element method using Comsol Multiphysics. The results of the steady-state model fit to the observation in the northern part of the study area, but this model predicts lower heat flow density and temperatures than observed in the southern part of the study area including the Styrian basin. The area underwent lithospheric stretching during the Early-Middle Miocene time, therefore the temperature field in the lithosphere is not steady-state. We calculated the initial temperature distribution in the lithosphere at the end of rifting using non-homogeneous stretching factors, and we modeled the present day thermal field. The results of the time-dependent model fit to the observed heat flow density and temperatures, except in those areas where intensive groundwater flow occurs in the carbonatic basement of the Transdanubian Range and Northern Calcareous Alps, and the metamorphic basement high between the Mura trough and Styrian basin. We conclude that time-dependent model is able to predict the temperature field in the upper 6-8 km of the crust, and is a valuable tool in EGS exploration.
\end{abstract}

\section{Lenkey}

lenkey@caesar.elte.hu

1 Eötvös Loránd University, Budapest, Hungary

2 Geologische Bundesanstalt, Vienna, Austria

3 Geološki zavod Slovenije, Ljubljana, Slovenia

4 Magyar Földtani és Geofizikai Intézet, Budapest, Hungary

5 Štátny Geologický Ústav Dionýza Štúra, Bratislava, Slovakia 
Keywords Heat flow density - Geothermal modeling - Geothermal reservoir - Pannonian basin

\section{Introduction}

The Pannonian basin is one of the most favorable areas in Europe to utilize geothermal energy owing to the high heat flow density (Hurter and Haenel 2002; Rajver and Ravnik 2002; Franko et al. 1995; Lenkey et al. 2002) and abundance of thermal water stored in the porous-permeable sediments and in the fractured basement (Goldbrunner 2000; Fendek and Fendekova 2010; Rman et al. 2015; Szanyi and Kovács 2010; Horváth et al. 2015). The geothermal resources are shared amongst the countries located in the area, therefore the sustainable production of thermal water requires coordinated actions. In the framework of the TransEnergy (TE) project the geological surveys of Austria, Hungary, Slovakia and Slovenia collected and harmonized the geological, hydrogeological and geothermal data in order to estimate the geothermal potential, register the geothermal installations, determine the rate of present day utilization and aid the future installations in the Alpine-Pannonian transition zone (Fig. 1). The geothermal data are presented in the forms of heat flow density map and temperature maps, which exhibit several geothermal anomalies. These anomalies can be interpreted by modeling the temperature distribution beneath the study

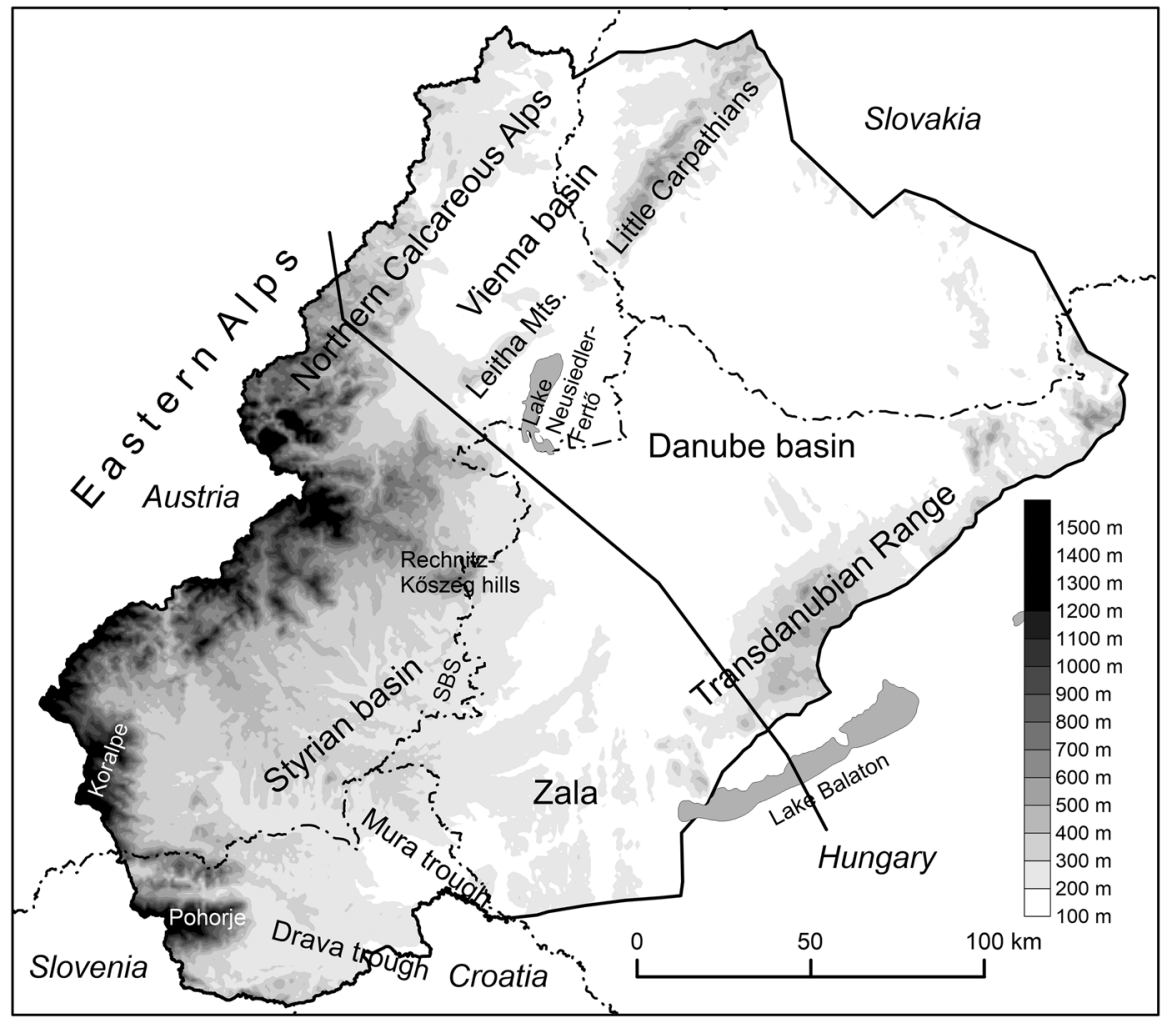

Fig. 1 Index map of the study area. SBS: South Burgenland Swell 
area. The modeling allows the extrapolation of temperature to large depth, which is crucial to understand the geodynamics of the lithosphere (Stüwe 2002; Cloetingh et al. 2010).

Several crustal and lithospheric scale temperature models were calculated in the Pannonian-Carpathian region before. Based on steady-state 2D thermal models along regional deep seismic sections Čermák and Bodri (1986) concluded that the high heat flow in the Pannonian basin originated from the mantle. On the contrary, 2D thermal balance calculations along a section in the Transylvanian basin explain the low heat flow density in the basin by normal mantle heat flow and reduced heat production rate in the upper crust built up of ophiolites (Andreescu et al. 2002). The Eastern Carpathians are characterized by normal heat flow density and it is in accordance with normal crustal structure and heat production rates as demonstrated by the steady-state thermal modelling along sections (Dérerová et al. 2006). In their model the crustal structure was derived from deep seismic sections, and gravity modelling. Surface heat flow density as boundary condition together with crustal structure and heat production rates were used by Lankreijer et al. (1999) to calculate the temperature distribution in the lithosphere and the integrated strength of the lithosphere along two sections crossing the Western Carpathians-Pannonian basin and Transylvanian basin-Eastern Carpathians. They concluded that the cold European foreland and the Ukrainian Shield comprised a mechanically strong frame of the Carpathians and the lithosphere of the hot internal parts was very weak. Time-dependent thermal models were used to take into correction the cooling effect of Neogene and Quaternary sedimentation on the heat flow density in the Pannonian basin (Lenkey 1999) and Transylvanian basin (Demetrescu et al. 2001) and determine the subsidence, thermal and maturation history of sediments in hydrocarbon exploration wells in the Pannonian basin (Horváth et al. 1988).

This paper presents the results of 3D conductive modeling of the temperature field in the lithosphere of the Alpine-Pannonian transition zone. We tested both steady-state and timedependent models in order to fit into the thermal data compiled in the TE project and draw conclusions about the heat transport processes in the study area.

\section{Geological setting}

The study area is surrounded by the Eastern Alps to the west, the Western Carpathians to the north and the Transdanubian Range to the south-east. The southern boundary follows the Slovenian-Croatian border until the Hungarian border and after crossing the Zala basin

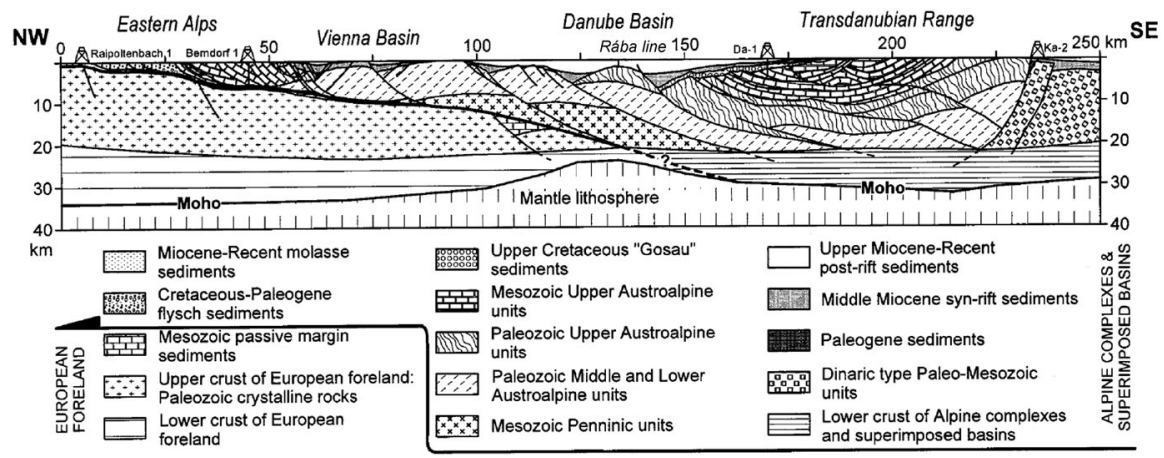

Fig. 2 Crustal scale tectonic section across the study area after Szafián et al. (1999). Location of the section is shown in Fig. 1 

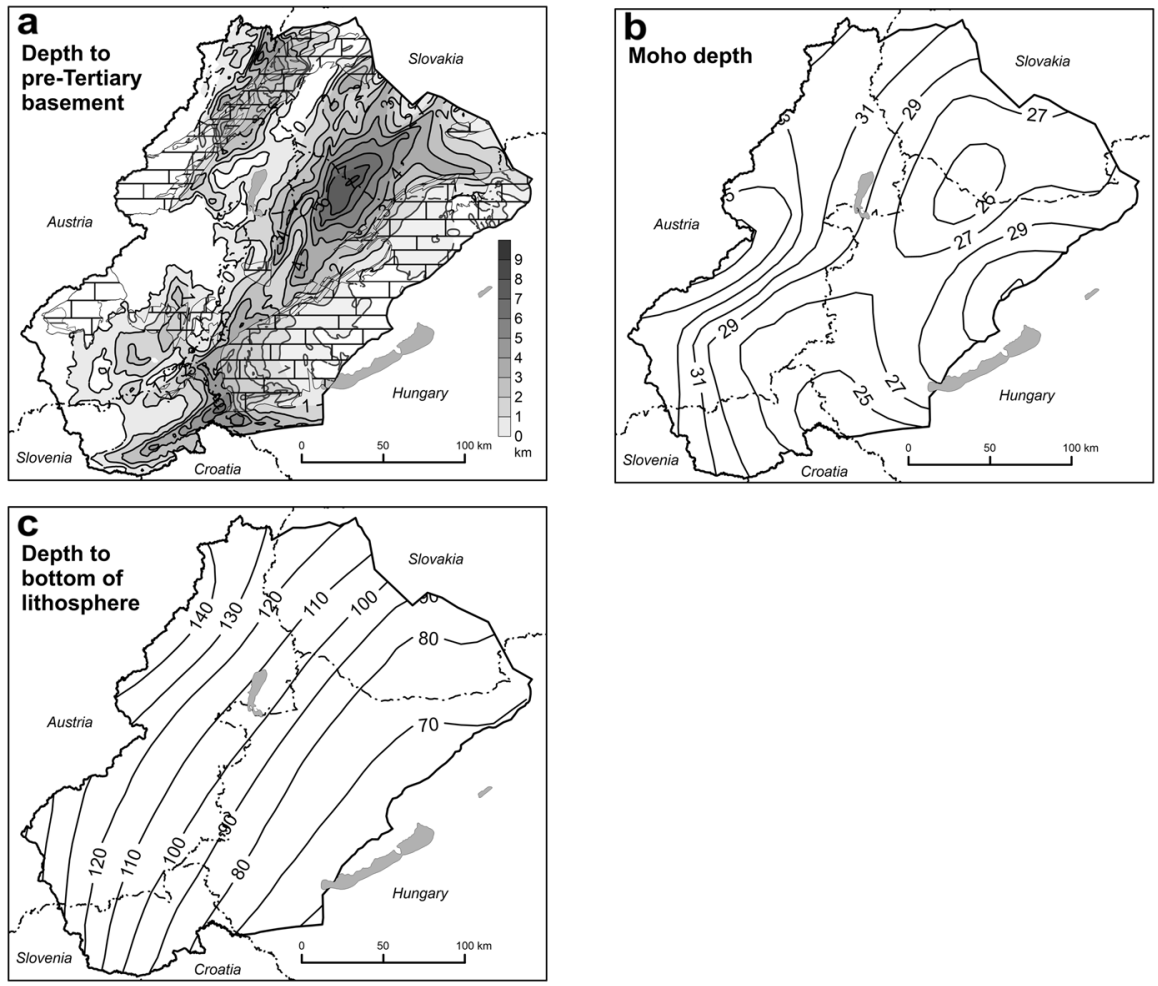

Fig. 3 The major horizons in the study area, which separate distinct rock types having different thermal properties. a Pre-Tertiary basement compiled by Maros (2012), b depth of the Mohorovičić discontinuity based on deep seismic lines listed in the text, c bottom of the lithosphere based on seismological observations and magnetotelluric soundings. In a the Mesozoic and older carbonatic rocks are also presented, because they comprise important geothermal reservoirs, where intensive karstic water flow is taking place influencing the thermal field

it joins to the Transdanubian Range (Fig. 1). In the study area several deep basins and troughs filled with Neogene and Quaternary sediments can be found (Figs. 2, 3a). These sediments unconformably overlie Mesozoic carbonates and Paleozoic metamorphic rocks belonging to the Austroalpine nappe system. Figure 2 shows a typical crustal section across the area illustrating the structure of the basement and the tectonic evolution of the Alpine-Pannonian transition zone after Szafián et al. (1999) and Schmid et al. (2008). The section is based on well data, industrial seismic lines and the deep reflection seismic line MK-1 from distance $100 \mathrm{~km}$ until $175 \mathrm{~km}$ (Ádám et al. 1984). The Vienna basin is located on the junction between the Eastern Alps and the Western Carpathians. It is interpreted as a sinistral pull-apart basin, which was opened along NE-SW trending shear zones during Early-Middle Miocene (Royden 1985; Wessely 1988; Fodor 1995). The basement consists of the Upper Austroalpine (Northern Calcareous Alps) and Lower Austroalpine nappes and allochtonous molasse and flysch sediments. The Vienna basin is separated from the Danube basin by the Little Carpathians and the Leitha Mts. In the northwestern part of the Danube basin south-east dipping low-angle normal faults control the formation of troughs and basement highs. The low-angle normal faults are the Middle Miocene rejuvenations of the pre-existing Cretaceous thrust faults of the Austroalpine nappe system (Tari and 
Horváth 2010). The Raba fault running in the middle of the basin in the NE-SW direction separates the Paleozoic Lower Austroalpine basement to the northwest from the Upper Austroalpine basement consisting of Triassic carbonates to the southeast (Szafián et al. 1999). The Styrian basin is located at the eastern margin of the Eastern Alps and the South Burgenland Swell separates it from the Danube basin. The northern part of the South Burgenland Swell comprises the Rechnitz window, where the Penninic basement of the Austroalpine nappes outcrops. It is interpreted as a metamorphic core complex (Tari et al. 1992) resulted from extensional unroofing of the footwall of a low-angle normal fault. The rapid uplift of the Rechnitz window (Dunkl and Demény 1997) was contemporaneous with basement subsidence (Gross et al. 2007). The Mura trough was opened along a ENE-WSW trending transtensional fault systems (Fig. 3a) during Early Miocene time (Jelen and Rifelj 2003). The Zala basin was formed by a NW-SE trending listric fault system active in Early-Middle Miocene (Fodor et al. 2011).

The driving mechanism of the extension in the Pannonian basin was subduction rollback of the Magura oceanic plate beneath the Carpathians lasting from Early Miocene until early Late Miocene (Royden et al. 1983a; Csontos et al. 1992; Horváth et al. 2015). In the Alpine-Pannonian transition zone extrusion tectonics also strongly influenced the style of extension (Ratschbacher et al. 1991a, b). The orogenic wedge of the Eastern Alps, formed due to the Late Oligocene-Early Miocene convergence between the Adriatic and European plate, escaped towards east from the collisional zone, and suffered extensional collapse along conjugate strike-slip fault systems. These strike-slip faults played an important role in the formation of the Vienna and Danube basins and the Mura trough. Other mechanisms as delamination and roll-back of the central Dinaric slab (Matenco and Radivojević 2012) and eastward mantle flow (Kovács et al. 2012) might have also contributed to the formation of the Pannonian basin.

Until Late Miocene mainly clayey and marly sediments with interbedded sand layers were deposited in the basins of the study area (Kovač et al. 2004; Jelen and Rifelj 2005). In Late Miocene the area was occupied by the Lake Pannon (Magyar et al. 1999). The lake was filled up by a large delta system prograding from northwest and west (Magyar et al. 2013). First the Vienna basin was infilled, then the Danube and Zala basins, and coevally the Mura trough from west. In the central regions (Danube basin, Mura-Zala basin) the prograding delta deposited several kilometers wide and some 10 meters thick sheets of sand with good connectivity. In the central part the subsidence and sedimentation continued, and these permeable layers, the so called "Upper Pannonian reservoir", was buried under $2 \mathrm{~km}$ thick sediment pile. It is the main thermal water bearing layer in the Danube basin and the Mura-Zala basin (Rman et al. 2015; Horváth et al. 2015; Tóth et al. 2016). In the Vienna basin sediments were deposited in some $100 \mathrm{~m}$ thickness after Late Miocene, and in the Styrian basin even erosion occurred (Hölzel et al. 2008; Sachsenhofer et al. 1997). Therefore, in the peripheral basins the geothermal reservoirs in the Neogene sediments are restricted to a few local favorable layers in the Early-Middle Miocene strata.

Beside the regional Upper Pannonian reservoir and the smaller local reservoirs in the Neogene sediments karstified and fractured carbonates represent another important type of geothermal reservoirs in the area. The two most important reservoirs are developed in the Transdanubian Range and the Northern Calcareous Alps. In the outcropping areas meteoric water precipitates and after penetrating to large depth it rises to the surface along faults and discharges in warm springs close to the foot of the hills. Such springs are found at the Lake Hévíz at the SW edge of the Transdanubian Range and at Baden or Bad Vöslau at the NE edge of the Calcareous Alps. 


\section{Basement, crustal and lithospheric structure}

The pre-Tertiary basement presented in Fig. 3a was edited in the framework of TE by unifying and harmonizing the national basement maps (Maros 2012). 1672 boreholes were reevaluated and several $100 \mathrm{~km}$ of seismic sections were interpreted in order to update the basement depth.

The crustal thickness is very well known in the area, because several deep seismic lines and 3D experiments investigated the transition of the Eastern Alps and the Pannonian region. The crustal thickness in Fig. 3b is based on deep seismic refraction line VI crossing the Vienna and Danube basins in NW-SE direction (Beránek and Zounková 1979), refraction lines ALP75 (Yan and Mechie 1989) and ST (Scarascia and Cassinis 1997) crossing the Styrian basin in W-E direction, reflection line 3T crossing the Vienna basin, Little Carpathians and northern part of the Danube basin (Tomek et al. 1987), line MK-1 (Ádám et al. 1984) interpreted in Fig. 2, line CEL-01 running in NE-SW direction in the Danube basin at the foot of the Transdanubian Range (Sroda 2006) and CEL-07 running in NW-SE direction along the Hungarian-Slovenian and Hungarian-Croatian borders (Kiss 2005). We also incorporated in the map the Moho map of the Eastern Alps based on tomographic inversions (Behm et al. 2007).

The lithospheric thickness is based on seismological observations (Babuška and Plomerová 1988; Babuška et al. 1990) and magnetotelluric soundings (Ádám 1996; Ádám et al. 1996, 1997). As these data are sparse the map shows interpolated values beneath the Styrian basin, and in general, in the southern part of the study area. In the recent years several upper mantle tomographic results were published for the Alpine-Pannonian-Dinaric region (Brückl 2011), where the lithospheric root of the Eastern Alps is well imaged by the negative velocity anomaly. Unfortunately, in those areas where the lithosphere is thinner than $150 \mathrm{~km}$ the models are not capable to resolve the lithospheric thickness. However, we note that in $150 \mathrm{~km}$ depth negative P-wave velocity anomalies exist both beneath the Mura-Zala basin and the Styrian basin (Mitterbauer et al. 2010), or only beneath the Mura-Zala basin (Koulakov et al. 2009). It might indicate that the lithosphere is thinner in these areas than indicated in Fig. 3c. Nevertheless, in the steady-state thermal model we used the given lithospheric thickness.

\section{Heat flow density and temperature}

The geothermal conditions of the study area are presented by means of the heat flow density map and temperature maps in 1 and $2.5 \mathrm{~km}$ depths (Fig. 4). The temperature data used for constructing the maps derive from steady-state temperature logs, corrected bottom hole temperatures, drill-stem tests, and corrected outflowing water temperatures from thermal wells (only HU). In Austria new thermal conductivity and heat production rate measurements were carried out on sediment samples. In the other countries thermal conductivities from previous measurements were used in estimating the heat flow density. The heat flow density map was constructed from 1243 data. Data coverage is suitable in the basin areas, but is poor in the Eastern Alps.

In the Vienna basin the heat flow density increases from less than $50 \mathrm{~mW} / \mathrm{m}^{2}$ in the north to more than $80 \mathrm{~mW} / \mathrm{m}^{2}$ in the south. The extreme values are caused by groundwater flow in the Mesozoic carbonates of the Calcareous Alps. The carbonate reservoir recharges at both outcrops in the SW and NE, and discharges in the southern Vienna basin. The heat 

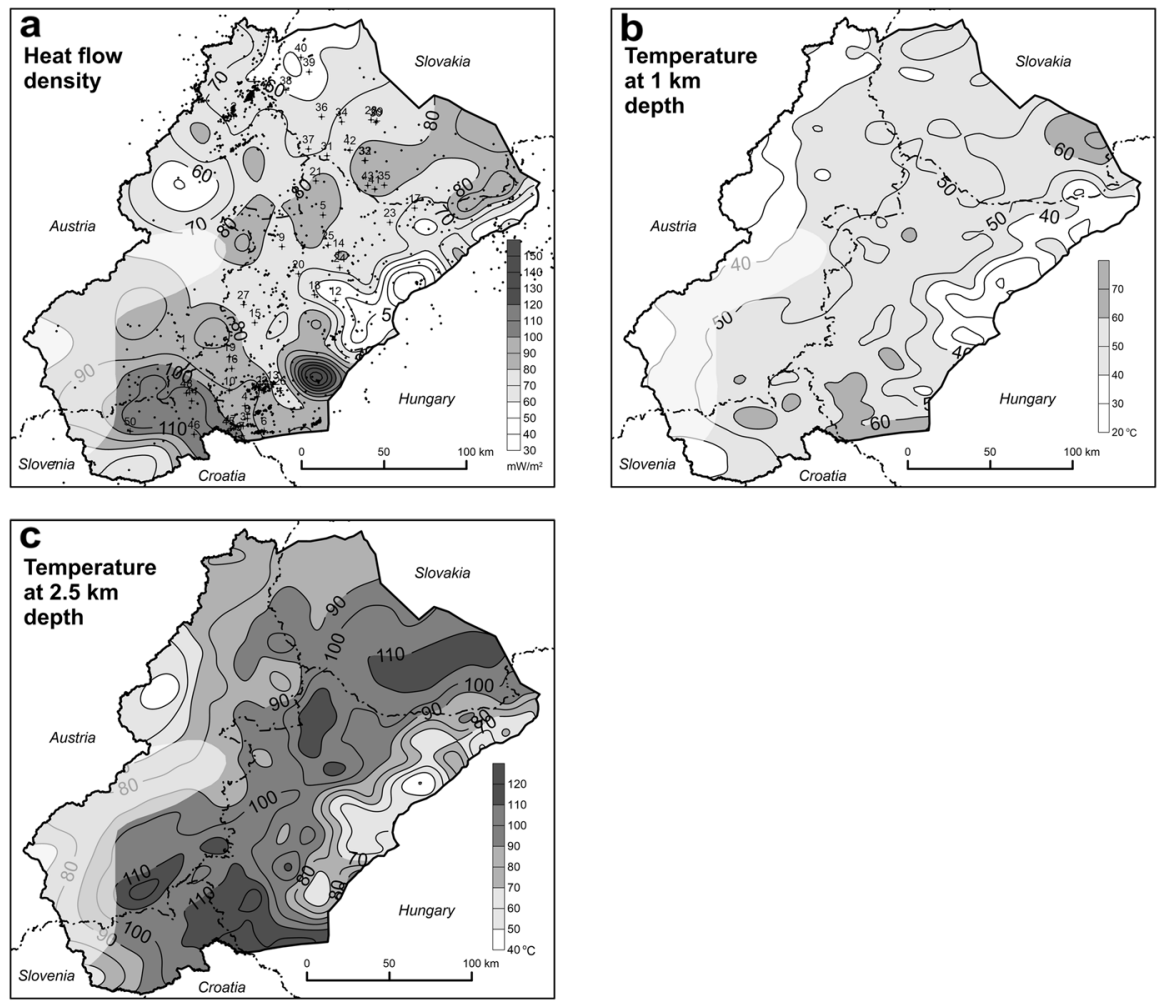

Fig. 4 Heat flow density and temperature maps of the study area compiled in the TransEnergy project. a Heat flow density map, dots: location of heat flow density estimates, crosses with numbers: wells in which thermal conductivity is known. Names of the wells are listed in Table 1 . b Temperature in $1 \mathrm{~km}$ depth below surface. c Temperature in $2.5 \mathrm{~km}$ depth. In the shaded area only few data exist

flow density in the Danube basin is $70-80 \mathrm{~mW} / \mathrm{m}^{2}$ with maximum values in the center and northeastern rim. The heat flow density in the study area, in general, increases towards south: in the Styrian basin it is over $90 \mathrm{~mW} / \mathrm{m}^{2}$, and in the Mura-Zala region it reaches more than $110 \mathrm{~mW} / \mathrm{m}^{2}$. The Transdanubian Range is characterized by very low heat flow density values of $30-50 \mathrm{~mW} / \mathrm{m}^{2}$ due to precipitation of meteoric water into the karstified limestones and dolomites. The water flows downward in NW direction in the basement of the Danube basin, and one branch turns to northeast and discharges in lukewarm springs at the northeastern edge of the mountains, in the Hungarian-Slovakian border zone. The other branch follows a path toward southwest and discharges in Lake Hévíz, where surface heat flow density is around $250 \mathrm{~mW} / \mathrm{m}^{2}$. The amount of heat discharged by the warm springs was summed, and the heat flow density in the Transdanubian Range was corrected by this value (Lenkey et al. 2002). Thus the heat flow density corrected for the karstic water flow would increase to $70-80 \mathrm{~mW} / \mathrm{m}^{2}$ in the area of the mountain range. It is not shown in Fig. $4 \mathrm{a}$, because it is based on the observed heat flow density values.

The temperature data measured in boreholes were inter- or extrapolated to $1 \mathrm{~km}$ and $2.5 \mathrm{~km}$ depths assuming conduction. Temperature in $1 \mathrm{~km}$ depth in the basin areas is around $50-60{ }^{\circ} \mathrm{C}$. The higher values are found in the southern part and in the northeastern rim of the Danube basin. The recharge areas of the carbonatic reservoirs have low temperatures of $20-30{ }^{\circ} \mathrm{C}$. In the discharge areas of the Transdanubian Range the temperature 
Table 1 Wells where thermal conductivity and temperature were measured

\begin{tabular}{|c|c|c|c|}
\hline No. & Well name & Short name & Data type \\
\hline \multicolumn{4}{|c|}{ Austria } \\
\hline 1 & Styrian basin & St-1 & $\mathrm{T}$ \\
\hline 2 & Vienna basin & W-3 & $\mathrm{T}$ \\
\hline \multicolumn{4}{|c|}{ Hungary } \\
\hline 3 & Lovászi-II & & $k, \mathrm{~T}$ \\
\hline 4 & Bárszentmihályfalva-1 & & $k$ \\
\hline 5 & Bősárkány-1 & & $k, \mathrm{~T}$ \\
\hline 6 & Budafa-I & & $k, \mathrm{~T}$ \\
\hline 7 & Újfalu-I & & $k$ \\
\hline 8 & Ortaháza-Ny1 & & $k$ \\
\hline 9 & Csapod-1 & & $k, \mathrm{~T}$ \\
\hline 10 & Csesztreg-I & & $k$ \\
\hline 11 & Szilvágy-33 & & $k$ \\
\hline 12 & Dabrony-1 & & $k$ \\
\hline 13 & Nagylengyel-II & & $k$ \\
\hline 14 & Tét-5 & & $k$ \\
\hline 15 & Egyházasdaróc-1 & & $k$ \\
\hline 16 & Öriszentpéter-2 & & $k$ \\
\hline 17 & Gönyü-1 & & $k, \mathrm{~T}$ \\
\hline 18 & Celldömölk-ENy1 & & $k$ \\
\hline 19 & Ivánc-1 & & $k$ \\
\hline 20 & Mihályi-28 & & $k$ \\
\hline 21 & Mosonszolnok-1 & & $k$ \\
\hline 22 & Nagylengyel-74 & & $k$ \\
\hline 23 & Pér-1 & & $k$ \\
\hline 24 & Vaszar-DNy1 & & $k$ \\
\hline 25 & Pásztori-1 & & $k$ \\
\hline 26 & Bak-5 & & $k$ \\
\hline 27 & Szombathely-II & & $k$ \\
\hline \multicolumn{4}{|c|}{ Slovakia } \\
\hline 28 & Galanta & FGG-1 & $k, \mathrm{~T}$ \\
\hline 29 & Galanta & FGG-2 & $k$ \\
\hline 30 & Galanta & FGG-3 & $k$ \\
\hline 31 & Cilistoc & FGC-1 & $k$ \\
\hline 32 & Dunajska Streda & DS-1 & $k$ \\
\hline 33 & Dunajska Streda & DS-2 & $k$ \\
\hline 34 & Králova pri Senci & VMK-1 & $k$ \\
\hline 35 & Calovo & $\mathrm{C}-1$ & $k$ \\
\hline 36 & Chorvátsko Grob & FGB-1 & $k$ \\
\hline 37 & Rusovce & HGB-1 & $k$ \\
\hline 38 & Láb & L-90 & $k$ \\
\hline 39 & Rohoznik & $\mathrm{R}-1$ & $k, \mathrm{~T}$ \\
\hline 40 & Závod & ZA-57 & $k$ \\
\hline
\end{tabular}


Table 1 continued

\begin{tabular}{llll}
\hline No. & Well name & Short name & Data type \\
\hline 41 & Ciliska Radvan & CR-1 & $k$ \\
42 & Horná Poton & FGHP-1 & $k$ \\
43 & Topolovec & VTP-11 & $k, \mathrm{~T}$ \\
Slovenia & & & $\mathrm{T}$ \\
44 & Moravske Toplice-2 & Mt-2/61 & $\mathrm{T}$ \\
45 & Petišovci-45 & Pt-45/53 & $k, \mathrm{~T}$ \\
46 & Ljutomer-1/88 & Ljut-1/88 & $k$ \\
47 & Petišovci-7/88 & Pg-7/88 & $k$ \\
48 & Pečarovci-1/91 & Peč-1/91 & $k, \mathrm{~T}$ \\
50 & Murski Gozd-6/85 & Mg-6/85 & $k$ \\
\hline
\end{tabular}

Thermal conductivities of these wells (except St-1 and W-3) were used to obtain the thermal conductivity of sediments in the model, the temperatures measured in the wells were compared to the modeled temperatures (Fig. 11). For location of the wells see Fig. 4a

was not extrapolated downward, because it would have resulted in extreme high temperatures.

The temperature in $2.5 \mathrm{~km}$ varies more than in $1 \mathrm{~km}$ depth. In the centers of the Danube basin and Mura-Zala basin the temperature is over $110^{\circ} \mathrm{C}$. In the Styrian basin the location of the maximum temperature $\left(120^{\circ} \mathrm{C}\right)$ is shifted to southern rim of the basin. The Vienna basin is slightly cooler compared to the other basins, it is characterized with temperature of $70-80{ }^{\circ} \mathrm{C}$.

\section{Description of the model}

\subsection{Physical model}

Assuming conduction the distribution of temperature in the lithosphere was calculated by solving the heat transport equation (e.g. Carslaw and Jaeger 1959):

$$
c \rho \frac{\partial T}{\partial t}=\frac{\partial}{\partial x}\left(k \frac{\partial T}{\partial x}\right)+\frac{\partial}{\partial y}\left(k \frac{\partial T}{\partial y}\right)+\frac{\partial}{\partial z}\left(k \frac{\partial T}{\partial z}\right)+A
$$

where $T$ is temperature, $c$ is specific heat, $\rho$ is density, $t$ is time, $k$ is thermal conductivity, and $A$ is volumetric heat production rate. $c, \rho, k$ and $A$ can vary in space. In steady-state the left side of the equation equals to zero.

We solved Eq. (1) with finite element method using Comsol Multiphysics. At the outer and internal boundaries the length of an edge of a tetraedric element was $200 \mathrm{~m}$, in general it increased downward, and in the mantle it reached $2 \mathrm{~km}$.

\subsection{Geometry of the model}

The model was built in UTM33 coordinate system and it includes three layers with their own material properties (Fig. 5). These layers in order are the Tertiary sediments, consisting mainly of Neogene sediments, crust and lithospheric mantle, bordered and divided by the following horizons: surface (Fig. 1), the depth of the pre-Tertiary basement, 


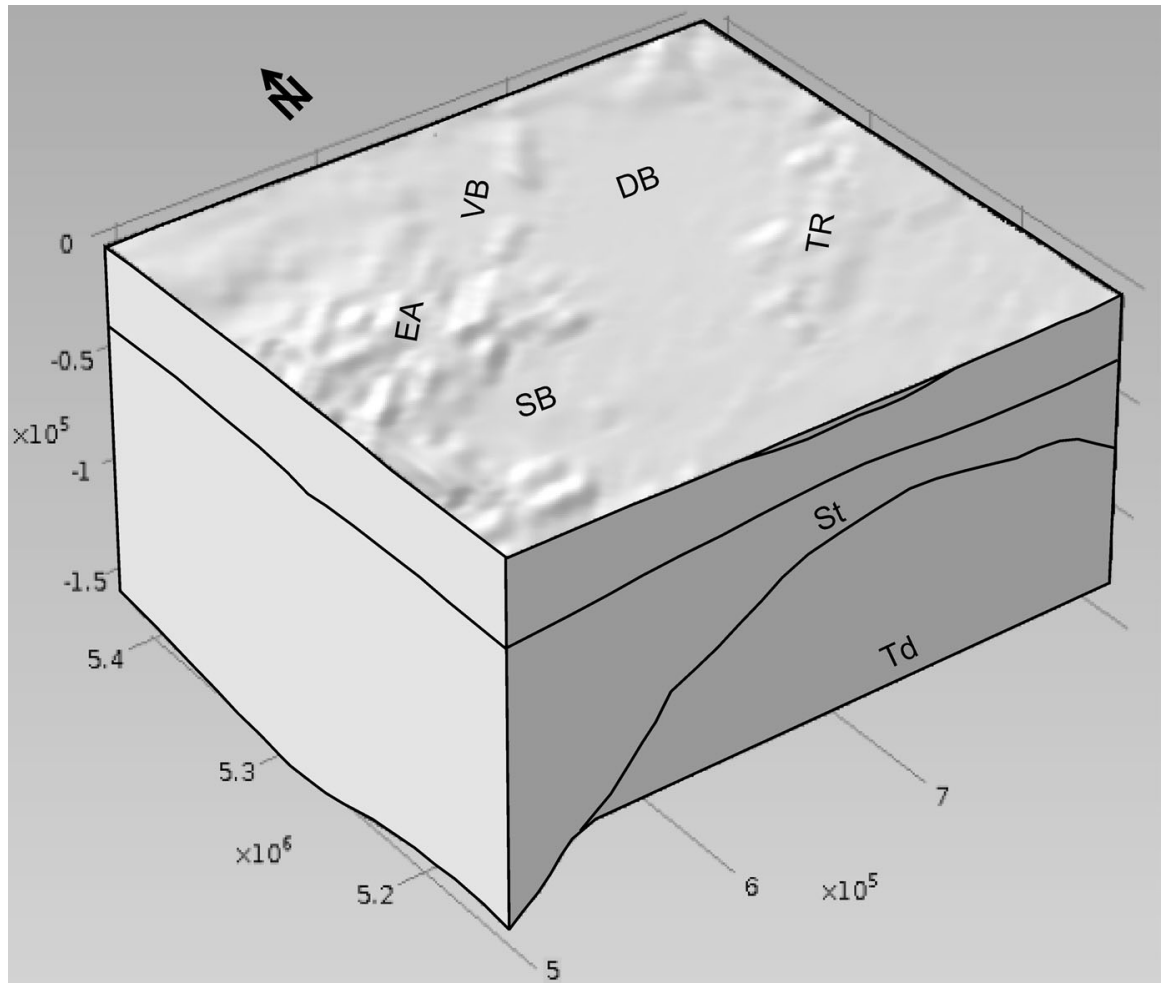

Fig. 5 The model block in which the temperature was calculated. St: bottom of the steady-state model, see Fig. 3c. $T d$ : bottom of the time-dependent model. $E A$ Eastern Alps, $V B$ Vienna basin, $D B$ Danube basin, $S B$ Styrian basin, $T R$ Transdanubian Range

Mohorovičić discontinuity, and the bottom of the lithosphere (Fig. 3). In case of the timedependent model the bottom of the model was in $125 \mathrm{~km}$ depth beneath basins and in areas where the thickness of the lithosphere is less than $125 \mathrm{~km}$. Otherwise the observed bottom of the lithosphere was used.

\subsection{Thermal properties of rocks}

In Eq. (1) the most important material properties are the thermal conductivity and heat production rate of rocks. Specific heat and density play a role only in the time-dependent model. We assumed that except for the sediments the lithosphere was homogeneous. We made this assumption, because we do not know in detail the spatial extent, especially the thickness of different rock types in the crust, e.g. the thickness of Triassic carbonates in the Transdanubian Range is unknown. The difference amongst the thermal conductivities of basement rocks (crystalline rocks, metamorphic rocks and carbonates) is less than the contrast between the thermal conductivities of the sediments and their basement. Thus, in spite of the simplification of a homogeneous crust, except for sediments, the model takes into account the first order features in the thermal conductivities.

The thermal conductivity of sediments varies both horizontally and vertically, due to changes in their composition (shales, marls, sandstones) and compaction. In the model we used the same thermal conductivities, which were applied in the heat flow density 
estimates. Except for Austria we chose wells, for which we knew the thermal conductivities of the drilled rocks, in Slovakia after Franko et al. (1995), in Hungary after Dövényi (1994), in Slovenia after Ravnik (1991) and Ravnik et al. (1995). These wells are given in Table 1, and the locations of the wells are shown in Fig. 4a. The thermal conductivity of a certain finite element belonging to the sediment layer in the model was calculated by horizontal and vertical extrapolation of the values given in the wells. The extrapolation was performed by the modelling software Comsol Multiphysics. In the Vienna and Styrian basins we used the mean values of the measured thermal conductivities, because they did not vary significantly with lithology, depth and age.

Thermal conductivities of crust and mantle were taken from Kappelmeyer and Haenel (1974) and Zoth and Haenel (1988).

The volumetric heat production rate in the crust and sediments was chosen $1 \mu \mathrm{W} / \mathrm{m}^{3}$. This value in the sediments derives from measurements on samples from the Vienna and Styrian basins. Considerations on the surface and mantle heat flow densities result in average continental heat production rate ranging between 0.79 and $0.99 \mu \mathrm{W} / \mathrm{m}^{3}$ (Jaupart and Mareschal 2014). Our value is on the high end, because the heat flow density is also high in the area. We neglected the heat production in the mantle, because it is two orders of magnitude less than in the crust.

The density of sediments, crust and mantle corresponds to the average values. We calculated the specific heat of rocks from the definition of the thermal diffusivity $(\kappa)$ : $\kappa=k / c \rho$. Thermal diffusivity was kept constant in the whole lithosphere $\left(8.23 \times 10^{-7} \mathrm{~m}^{2} / \mathrm{s}\right.$, after Royden and Keen 1980), and given the density and thermal conductivity of rocks specific heat was determined. The thermal parameters of the model are summarized in Table 2.

Sensitivity tests indicate that the temperature at the Moho can vary up to few $100{ }^{\circ} \mathrm{C}$ depending on the actual values of the heat production rate and thermal conductivities used in a thermal model (e.g. Baumann and Rybach 1991; Ellsworth and Ranalli 2002). We did not take into account that heat production was higher in the upper crust $\left(1.2-2 \mu \mathrm{W} / \mathrm{m}^{3}\right)$, and less in the lower crust $\left(0.4-0.6 \mu \mathrm{W} / \mathrm{m}^{3}\right)$ (Jaupart and Mareschal 1999; Andreescu et al. 2002). We also neglected that the thermal conductivity depended on the temperature reducing its value in the crust. Therefore, our model can predict the temperature in the lower crust and the mantle only with considerable error. However, the surface heat flow

Table 2 Thermal properties of rocks used in the model

\begin{tabular}{lllll}
\hline & $k\left(\mathrm{~W} / \mathrm{m}^{\circ} \mathrm{C}\right)$ & $A\left(10^{-6} \mathrm{~W} / \mathrm{m}^{3}\right)$ & $c\left(\mathrm{~J} / \mathrm{kg}{ }^{\circ} \mathrm{C}\right)$ & $\rho\left(\mathrm{kg} / \mathrm{m}^{3}\right)$ \\
\hline Styrian basin sediments & 2.4 & 1 & 1282 & 2300 \\
Vienna basin sediments & 2.7 & 1 & 1426 & 2300 \\
Sediments in other basins (HU, SK, SI) & Varies & 1 & 1282 & 2300 \\
& $(1.5-2.8)$ & & 1374 & 2800 \\
Crust & 3 & 1 & 1554 & 3300 \\
Mantle & 4 & 0 & & \\
\hline
\end{tabular}

$k$ thermal conductivity, $A$ volumetric heat production rate, $c$ specific heat, $\rho$ density

$k$ and $A$ data in Vienna and Styrian basins are mean values from laboratory measurements made in the framework of TE project. Thermal conductivity of sediments in the other areas comes from wells; HU: Dövényi (1994), SK: Franko et al. (1995), SI: Ravnik (1991), Ravnik et al. (1995), thermal conductivities of crust and mantle are from (Kappelmeyer and Haenel 1974; Zoth and Haenel 1988) Densities are mean values. Specific heat is calculated from $\kappa=k / c \rho$ assuming that $\kappa$ is constant $\left(8.23 \times 10^{-7} \mathrm{~m} / \mathrm{s}^{2}\right.$, Royden and Keen 1980) 
density is much less sensitive to the variation of the thermal conductivities. We calculated the surface heat flow density in a steady-state model, where the thickness of the crust and lithosphere was 35 and $125 \mathrm{~km}$, respectively, the heat production rate in the crust was $1 \mu \mathrm{W} / \mathrm{m}^{3}$, the temperature at the bottom of the lithosphere was $1300{ }^{\circ} \mathrm{C}$ (McKenzie 1978), and $10{ }^{\circ} \mathrm{C}$ at the surface, and the thermal conductivity varied in the crust and mantle. In the interesting range of crustal and mantle thermal conductivities the surface heat flow density varies between 58 and $63 \mathrm{~mW} / \mathrm{m}^{2}$ (Fig. 6). The latter value is obtained with the thermal properties listed in Table 2, and it is in agreement to the average heat flow density value in Europe (Majorowicz and Wybraniec 2011). Therefore, we conclude that the thermal parameters we used in modeling are suitable to model the surface heat flow density and predict the temperature until about $10 \mathrm{~km}$ depth.

\subsection{Boundary and initial conditions}

At the surface $10{ }^{\circ} \mathrm{C}$, and at the bottom of the model $1300{ }^{\circ} \mathrm{C}$ were prescribed. The vertical sides of the model were insulating.

In case of the time-dependent solution of Eq. 1 initial temperature distribution must be defined. The Early-Middle Miocene extension affected the whole lithosphere of the Pannonian basin as evidenced by the attenuated crust and lithosphere, and high heat flow density (Figs. 3, 4). In the early 1980s Sclater et al. (1980) and Royden et al. (1983b) showed that the high post-rift subsidence rate and the observed high heat flow density could

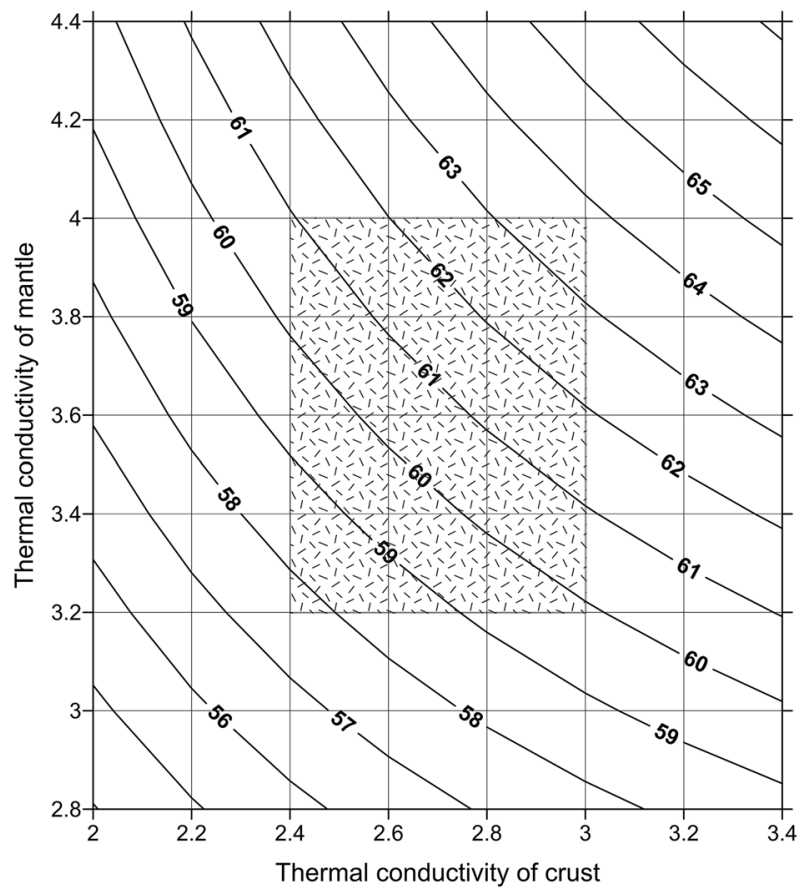

Fig. 6 Steady-state surface heat flow density (in $\mathrm{mW} / \mathrm{m}^{2}$ ) as a function of crustal and mantle thermal conductivities. Model set up: crustal and lithospheric thicknesses are 35 and $125 \mathrm{~km}$, respectively, heat production in the crust equals to $1 \mu \mathrm{W} / \mathrm{m}^{3}$, no heat production in the mantle, top and bottom temperatures are 10 and $1300{ }^{\circ} \mathrm{C}$, respectively. The hatched area indicates the range of thermal conductivities generally used in modeling 
only be explained if the mantle part of the lithosphere were stretched more than the crust. The following applications of the stretching model corroborated this observation (Royden and Dövényi 1988; Lankreijer et al. 1995; Sachsenhofer et al. 1997; Lenkey 1999).

In the stretching model of the lithosphere (sensu McKenzie 1978; Royden and Keen 1980) the lithosphere is stretched instantaneously during the rifting phase, which results in high geothermal gradient in the attenuated part of the lithosphere (Fig. 7). After the rifting phase the high temperature in the lithosphere relaxes back to the original geotherm.

It seems suitable to use the stretching factors derived by Lenkey (1999) for the whole Pannonian basin to calculate the initial temperature distribution in the present model. First we calculated the steady-state geotherm with thermal parameters given in Table 2, boundary conditions defined in this chapter, and assuming initial crustal and lithospheric thicknesses of 35 and $125 \mathrm{~km}$, respectively (Fig. 7). We determined initial geotherms in the study area in a grid with $5 \mathrm{~km}$ spacing by compressing the steady-state geotherm with the stretching factors presented in Fig. 8. In those places, where stretching did not occur we kept the steady-state geotherm. The initial temperature values in the nodes of the finite element mesh were obtained by extrapolation of the temperature values of the initial geotherms in the grid.

We assumed that the stretching of the lithosphere was instantaneous, and occurred 17.5 Ma before present, which was the start of the time-dependent calculation.

\section{Results}

The results of the steady-state modeling are presented in Fig. 9. The modeled heat flow density reflects the thickness of the lithosphere. As the temperature at the base of the lithosphere is fixed and the thickness of the lithosphere decreases from NW towards SE

Fig. 7 Examples of geotherms used in the modeling. Solid line: steady-state temperature in the lithosphere, for parameters see caption of Fig. 6. Dashed line: initial geotherm in the timedependent model calculated from the steady-state geotherm by stretching

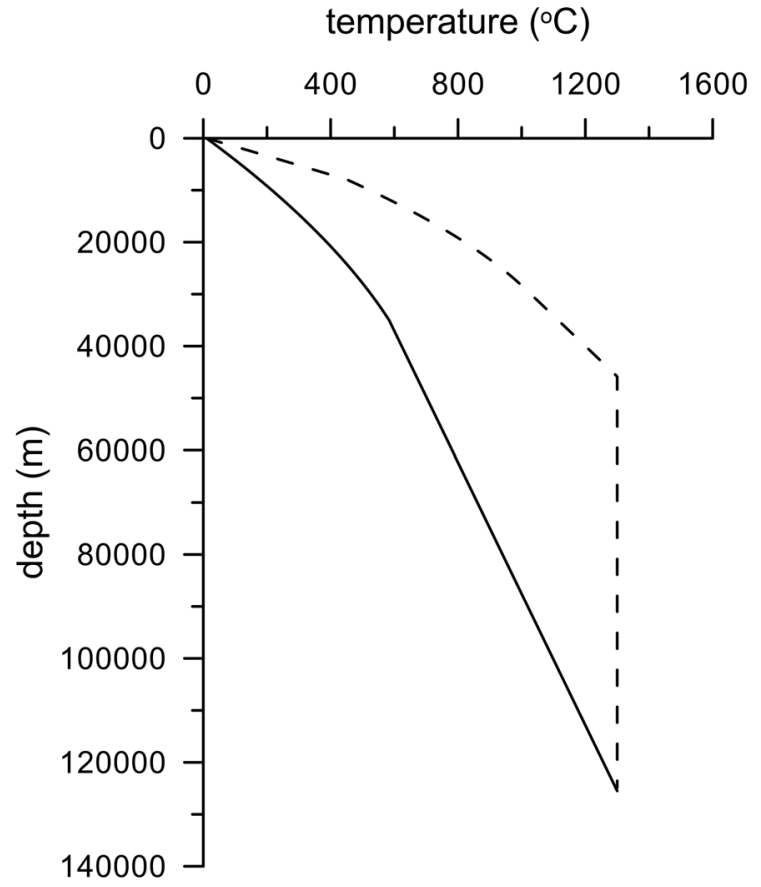



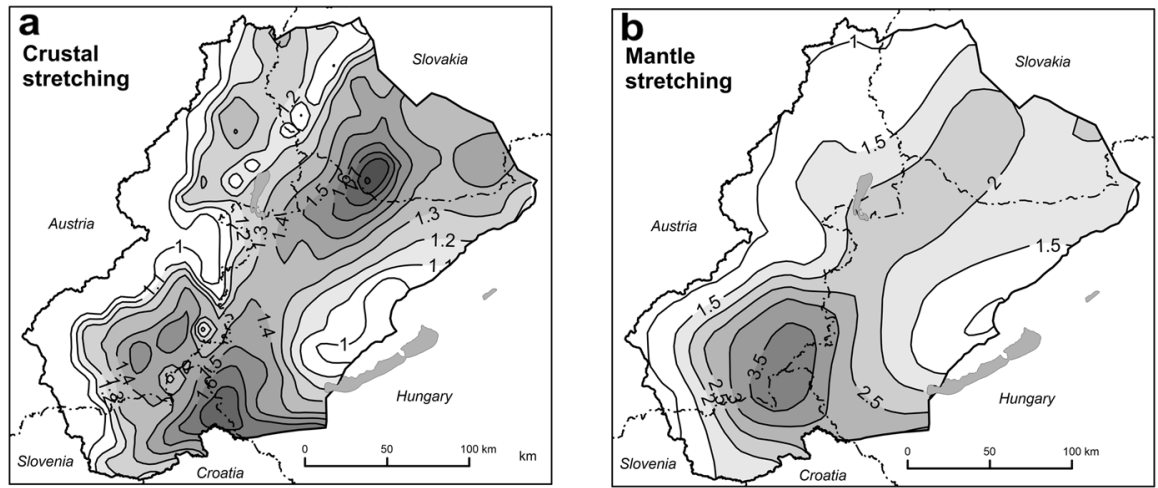

Fig. 8 Stretching factors in the time-dependent model, which were used to calculate the initial geotherm, see Fig. 7
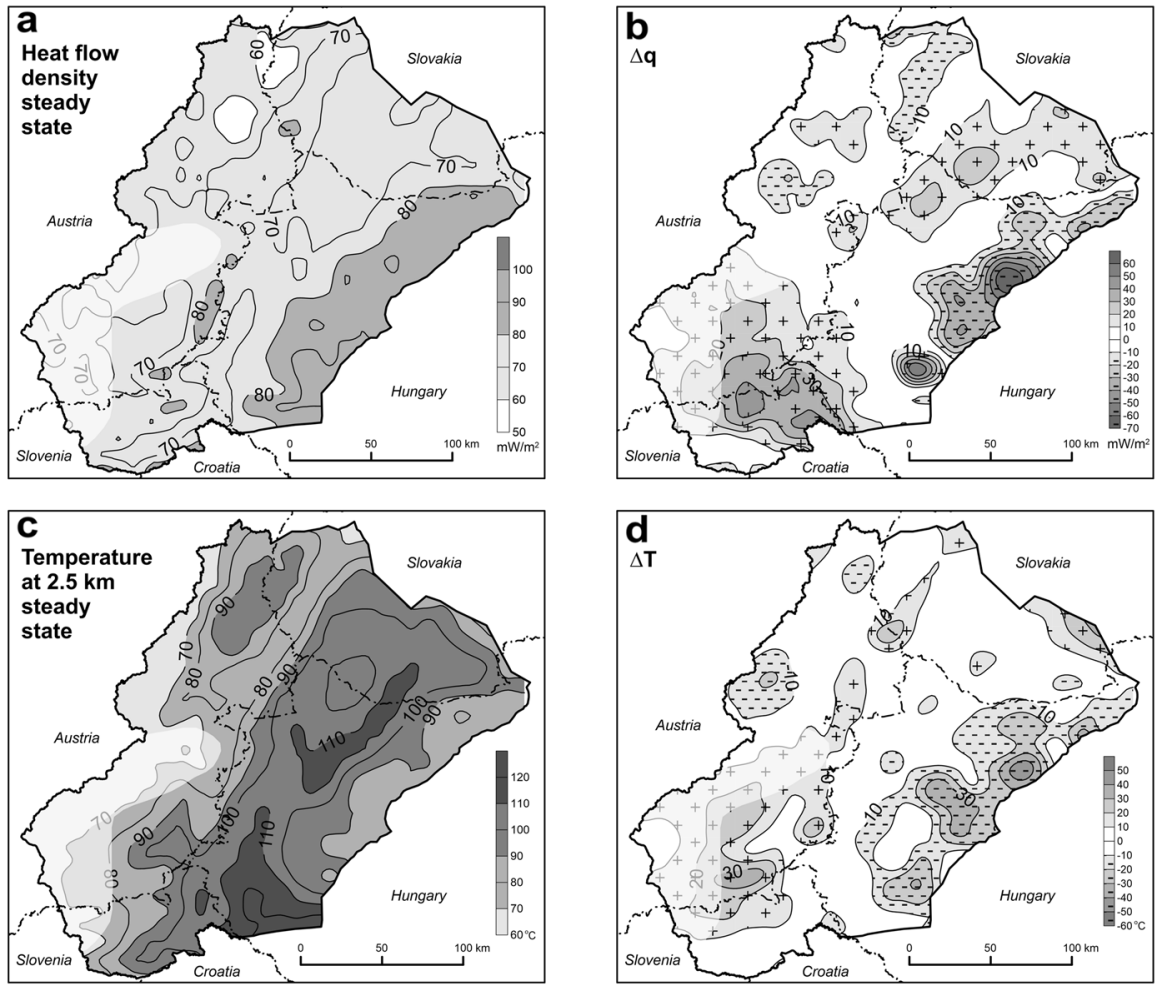

Fig. 9 Results of the steady-state model. a Modeled heat flow density. b The difference between the observed and modeled heat flow densities, negative where observed heat flow density is lower than modeled, positive vice versa. c Modeled temperature in $2.5 \mathrm{~km}$ depth. d The difference between the observed and modeled temperatures, negative where observed temperature is lower than modeled, positive vice versa

(Fig. 3c), the geothermal gradient in the lithosphere, and thus the heat flow density increases towards SE. This tendency is slightly perturbed by the variation of the crustal thickness and the refraction of heat flow. Below the Danube basin and Mura-Zala basin the 
crust is thin, thus less heat is produced. Additionally, the sediments have lower thermal conductivity than the crust, thus heat flow is diverted towards the basement flanks. The superposition of these two effects results in the local heat flow density minima in the center of the basins and heat flow density maximum in the South Burgenland Swell. The temperature map exhibits the blanketing effect of sediments: the temperature in each basin is high relative to the basin flanks. It follows from the Fourier law if the thermal conductivity reduces, then the geothermal gradient increases, providing that the heat flow density is constant. The effect clearly exists in the basin areas in spite of the fact that the heat flow density is slightly reduced in the basin centers as discussed above. This reduction in the heat flow density causes that the maximum temperature in the Danube basin shifts to southeast.

It is evident that our conductive model is not able to reproduce the convective thermal anomalies. The observed heat flow density is lower in the areas cooled by downward groundwater flow (negative values in the difference maps), and higher in the discharge areas (positive values in the difference maps in the Southern Vienna basin and around Lake Hévíz) than the modeled values.

In the southern part of the study area the steady-state model predicts $30-40 \mathrm{~mW} / \mathrm{m}^{2}$ less heat flow density than observed. There are indications that upward groundwater flow occurs in the basement along faults in this area (Kraljić et al. 2005), but thermal anomalies of such origin are restricted to smaller areas compared to the large positive anomaly shown in Fig. 9b, d. Therefore, in the area of this anomaly we reject the model.

In the time-dependent model (Fig. 10), the heat flow density and temperature in the southern part of the study area are considerably increased, additionally, the heat flow density is about $10 \mathrm{~mW} / \mathrm{m}^{2}$ higher in the center of the Danube basin. These changes improve significantly the fit between the observed and modeled quantities. In the southern part of the area, at the Austrian-Slovenian border the heat flow density and the temperature are still higher than the modeled values (Figs. 10b, d). We attribute these anomalies to groundwater flow as suggested by Kraljić et al. (2005).

The models are best constrained at those wells, where the thermal conductivity of sediments is known (Table 1). We chose few wells, in which temperature measurements were made. The modelled and observed temperatures along these control wells are shown in Fig. 11. In the northern part of the study area both the steady-state and the timedependent model result in good fit to the observed temperatures. The only exception is the well Gönyü-1, where the modeled values are higher. At this location groundwater flow takes part in the carbonatic basement, which explains why both models predict higher temperatures than the observed ones. The temperature data are confusing in the Bösárkány1 well. The modeled temperatures fit to the measured values in shallow depth, but it is difficult to explain the high temperatures in $4 \mathrm{~km}$ depth. Either the data are wrong or groundwater flow is taking place in the shallow sediments. We leave open this question. In the southern part of the study area the steady-state model misfits to the measured data, and the time-dependent model improves the fit. However, at the wells Petišovci-45, Moravske Toplice-2 and Murski Gozd-6 the measured temperatures are very high. As discussed above these high temperatures might be attributed to groundwater flow. In the Ljutomer-1 well the situation is opposite: the models overestimate the observed temperatures. The temperature gradient seems to increase with depth, therefore either downward groundwater flow occurs in the sediments near the well, or more likely the curvature, still visible in the measured geotherm, is a consequence of influence of the last ice age (Würm) push which slowly penetrates in depth and slowly dwindles in time (Šafanda and Rajver 2001). 

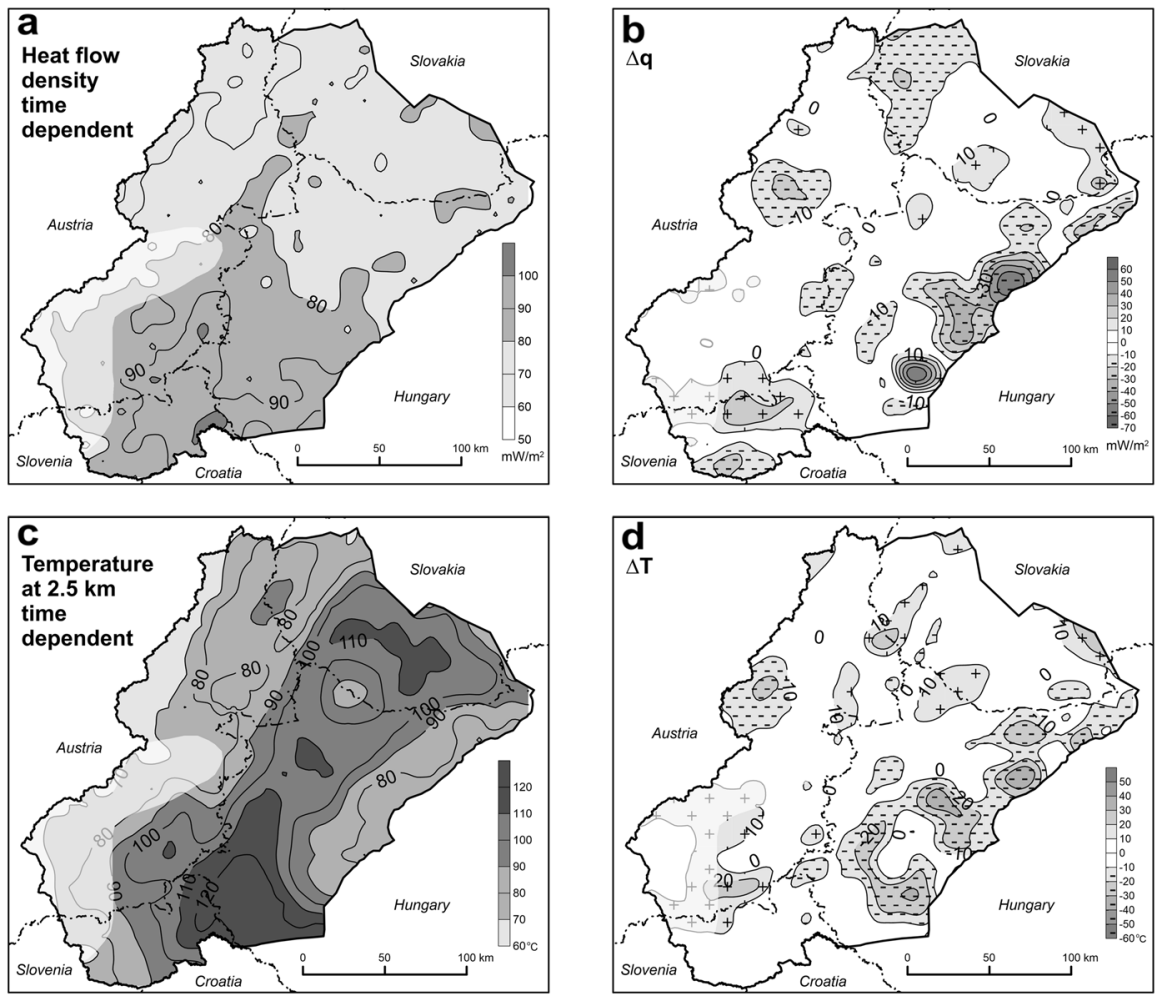

Fig. 10 Results of the time-dependent model. For detailed description see caption Fig. 9

Either in the maps or in the temperature logs most of the differences between the observed and modeled heat flow densities and temperatures occur in those places where groundwater flow is taking place.

\section{Discussion and conclusions}

In stable continental areas the variation of heat flow density mainly depends on the crustal heat production. However, in an extensional tectonic setting the heat flow density is mainly influenced by the lithospheric thickness. The results of the steady-state model revealed that in the southern part of the study area, where the lithospheric thickness is not reliable, the model is not capable to reproduce the heat flow density and the measured temperatures. The time-dependent model leads to much better fit to the observations. This model contains stretching factors, and one possible interpretation of the stretching factor is that the lithosphere indeed attenuates. This interpretation leads to the conclusion that beneath the Styrian basin and Mura-Zala basin the lithosphere is thinner than indicated on the present lithospheric thickness map. The other interpretation of the mantle thinning is that surplus heat is added to the lithosphere by some mantle process. This interpretation is supported by seismic tomographic images that show anomalously low velocities, and thus high temperature beneath these basins (Koulakov et al. 2009; Mitterbauer et al. 2010). We may accept any one of the two interpretations, because 

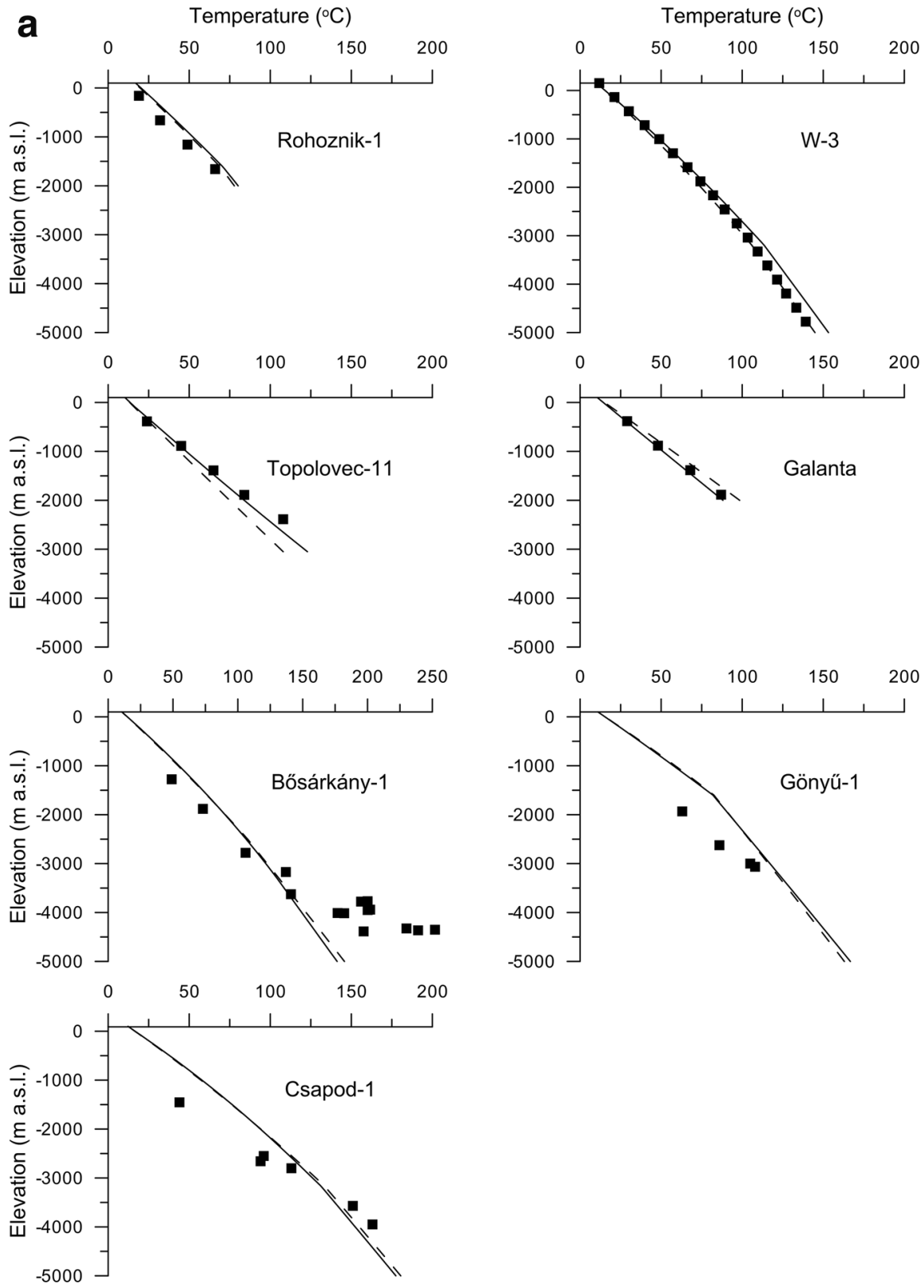

Fig. 11 Observed and modeled temperatures in control wells, where thermal conductivity is known and temperature measurements were carried out. Rectangles: measured values, solid line: steady-state model temperature, dashed line: time-dependent model temperature. Location of the wells is shown in Fig. 4a, and number of the wells is listed in Table 1

from the viewpoint of the thermal regime of the lithosphere they are equivalent. It is an important conclusion that care must be taken in those lithospheric scale thermal models in which the temperature is prescribed at the bottom of the lithosphere. In such models 


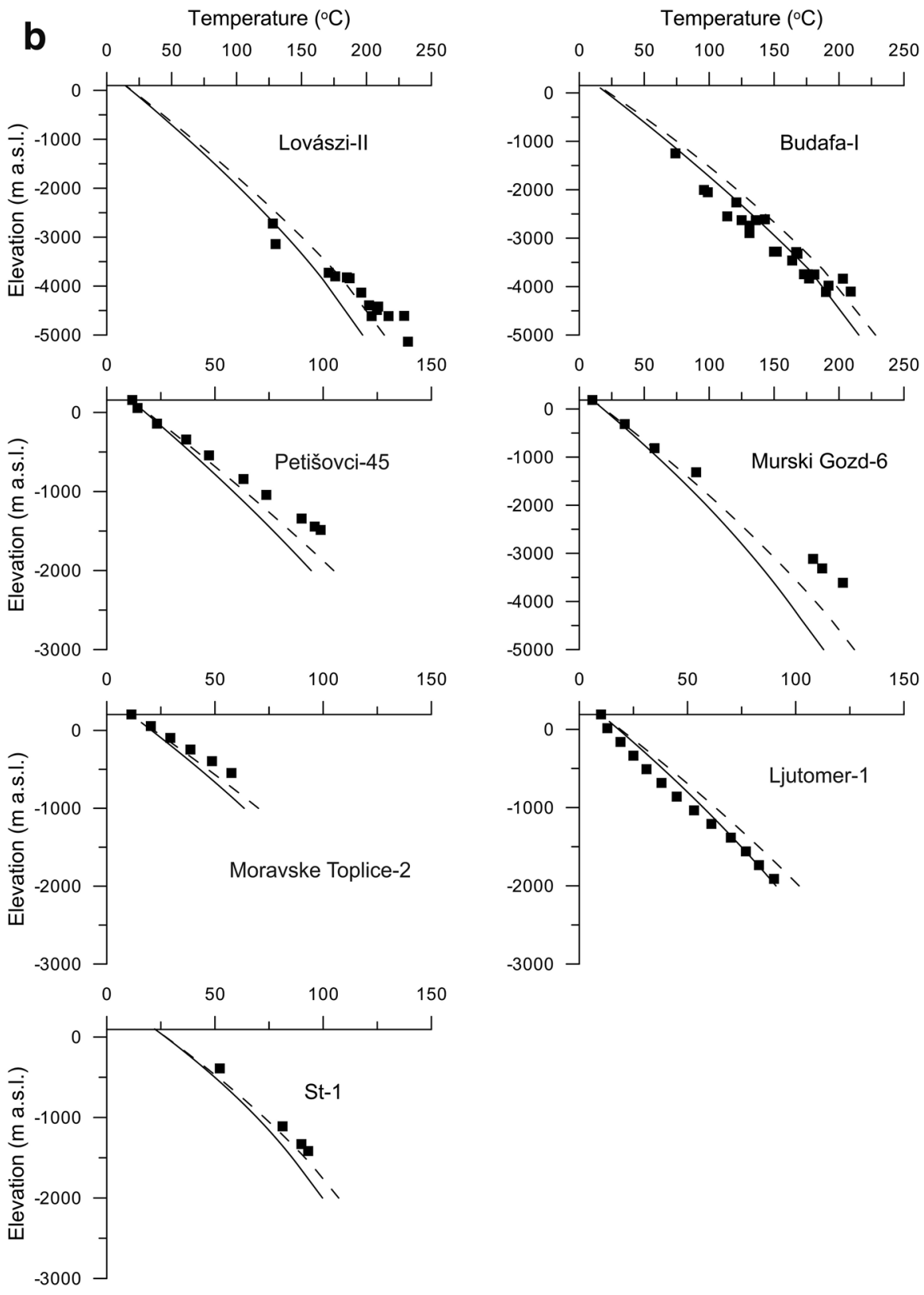

Fig. 11 continued

good controls on the lithospheric thickness and the temperature at the base of the lithosphere is required.

In case of the time-dependent model, the modeling results differ from the observations mainly in those areas where groundwater flow is taking place in the basement. Apart from these places the model is in accordance with the observations. Therefore, we strongly 
believe that this model describes well the conductive thermal field in the upper 6-8 $\mathrm{km}$ of the crust. Thus, the model can be used to screen target areas for EGS exploration.

In the future it is possible to refine the model. Collecting more information on the structure of the crust and the heat production rate of the upper crustal rocks will lead to more precise estimation of the temperature in the lower crust and upper mantle.

Acknowledgements The TransEnergy project was supported by the Central Europe Program, 2CE124P3. The research presented in this paper was carried out in cooperation amongst the Department of Geophysics and Space Science, Eötvös Loránd University, Magyar Földtani és Geofizikai Intézet, Geologische Bundesanstalt, Geološki zavod Slovenije and Štátny Geologický Ústav Dionýza Štúra.

\section{References}

Ádám A (1996) Regional magnetotelluric (MT) anisotropy in the Pannonian basin (Hungary). Acta Geod Geophys Hung 31(1-2):191-216

Ádám O, Haas J, Nemesi L, Tátrai MR, Ráner G, Varga G (1984) Geophysical investigations along geological key sections. Annu Rep Eötvös L. Geophys Inst Hung 1983:37-44 (in Hungarian with English abstract)

Ádám A, Szarka L, Prácser E, Varga G (1996) Mantle plumes or EM distortions in the Pannonian basin? (Inversion of deep magnetotelluric (MT) soundings along the Pannonian Geotraverse). Geophys Trans 40(1-2):45-78

Ádám A, Ernst T, Jankowski J, Jozwiak W, Hvozdara M, Szarka L, Wesztergom V, Logvinov I, Kulik S (1997) Electromagnetic induction profile (PREPAN95) from the east European platform (EEP) to the Pannonian basin. Acta Geod Geophys Hung 32(1-2):203-223

Andreescu M, Nielsen SB, Polonic G, Demetrescu C (2002) Thermal budget of the Transylvanian lithosphere. Reasons for a low surface heat-flux anomaly in a Neogene intra-Carpathian basin. Geophys J Int 150:494-505

Babuška V, Plomerová J (1988) Subcrustal continental lithosphere: a model of its thickness and anisotropic structure. Phys Earth Planet Inter 51:130-132

Babuška V, Plomerová J, Granet M (1990) The deep lithosphere in the Alps: a model inferred from P residuals. Tectonophysics 176:137-165

Baumann M, Rybach L (1991) Temperature field modelling along the northern segment of the European Geotraverse and the Danish Transition Zone. Tectonophysics 194(4):387-407

Behm M, Brückl E, Chwatal W, Thybo H (2007) Application of stacking and inversion techniques to 3D wide-angle reflection and refraction seismic data of the Eastern Alps. Geophys J Int 170(1):275-298

Beránek B, Zounková M (1979) Principal results of deep seismic soundings. In: Vanêk J, Babuška V, Plancár J (eds) Geodynamic investigations in Czechoslovakia. Final. Rep., Veda Publ. House, Bratislava, pp 105-111

Brückl E (2011) Lithospheric structure and tectonics of the eastern Alps-Evidence from new seismic data. In: Closson D (ed) Tectonics. InTech. pp 39-64. doi:10.5772/567

Carslaw HS, Jaeger JC (1959) Conduction of heat in solids. Clarendon Press, Oxford, pp 1-510

Čermák V, Bodri L (1986) Two-dimensional temperature modelling along five East-European geotraverses. J Geodyn 5:133-163

Cloetingh S, van Wees JD, Ziegler PA, Lenkey L, Beekman F, Tesauro M, Förster A, Norden B, Kaban M, Hardebol N, Bonté D, Genter A, Guillou-Frottier L, Ter Voorde M, Sokoutis D, Willingshofer E, Cornu T, Wórum G (2010) Lithosphere tectonics and thermo-mechanical properties: an integrated modelling approach for Enhanced Geothermal Systems exploration in Europe. Earth Sci Rev 102:159-206. doi:10.1016/j.earscirev.2010.05.003

Csontos L, Nagymarosy A, Horváth F, Kovác M (1992) Tertiary evolution of the Intra-Carpathian area: a model. Tectonophysics 208:221-241

Demetrescu C, Nielsen SB, Ene M, Serban DZ, Polonic G, Andreescu M, Pop A, Balling N (2001) Lithosphere thermal structure and evolution of the Transylvanian Depression-insights from new geothermal measurements and modelling results. Phys Earth Planet Inter 126:249-267

Dérerová J, Zeyen H, Bielik M, Salman K (2006) Application of integrated geophysical modeling for determination of the continental lithospheric thermal structure in the Eastern Carpathians. Tectonics 25:TC3009. doi:10.1029/2005TC001883 
Dövényi P (1994) Geophysical investigations of the lithosphere of the Pannonian basin. PhD Thesis, Eötvös Univ, Budapest, p 127

Dunkl I, Demény A (1997) Exhumation of the Rechnitz window at the border of the Eastern Alps and Pannonian basin during Neogene extension. Tectonophysics 272:197-211

Ellsworth C, Ranalli G (2002) Crustal temperatures in the Variscan massif of southern Portugal: an assessment of effects of parameter variations. J Geodyn 34:1-10

Fendek M, Fendekova M (2010) Country Update of the Slovak Republic. In: Proceedings, World Geothermal Congress, IGA, Bali

Fodor L (1995) From transpression to transtension: Oligocene-Miocene structural evolution of the Vienna basin and the East Alpine-Western Carpathian junction. Tectonophysics 242:151-182

Fodor L, Uhrin A, Palotás K, Selmeczi I, Tóthné Makk Á, Rižnar I, Trajanova M, Rifelj H, Jelen B, Budai T, Koroknai B, Mozetič S, Nádor A, Lapanje A (2011). A Mura-Zala medence vízföldtani elemzést szolgáló földtani-szerkezetföldtani modellje. (Geological and structural model of the Mura-Zala Basin and its rims as a basis for hydrogeological analysis.) Magyar Állami Földtani Intézet Évi jelentése, pp 47-92

Franko O, Remsik A, Fendek M (eds) (1995) Atlas geotermálnej energie Slovenska. Geologicky ústav Dionyza Stúra, Bratislava

Goldbrunner JE (2000) Hydrogeology of deep groundwaters in Austria. Mitt Österr Geol Ges 92:281-294

Gross M, Fritz I, Piller WE, Soliman A, Harzhauser M, Hubmann B, Moser B, Scholger R, Suttner T, Bojar HP (2007) The Neogene of the Styrian Basin. Guide to Excursions (Das Neogen des Steirischen Beckens - Exkursionführer). Joannea Geologie und Palaeontologie 9:117-193

Hölzel M, Wagreich M, Faber R, Strauss P (2008) Regional subsidence analysis in the Vienna basin (Austria). Austr J Earth Sci 101:88-98

Horváth F, Dövényi P, Szalay Á, Royden LH (1988) Subsidence, thermal and maturation history of the Great Hungarian Plain. In: Royden LH, Horváth F (eds) The Pannonian Basin, a study in basin evolution (vol 45). Amer. Assoc. Petr. Geol. Mem., Tulsa, pp 355-372

Horváth F, Musitz B, Balázs A, Végh A, Uhrin A, Nádor A, Koroknai B, Pap N, Tóth T, Wórum G (2015) Evolution of the Pannonian basin and its geothermal resources. Geothermics 53:328-353

Hurter S, Haenel R (eds) (2002) Atlas of Geothermal Resources in Europe. Office for Official Publications of the European Communities, Luxembourg

Jaupart C, Mareschal JC (1999) The thermal structure and thickness of continental roots. Lithos 48:93-114

Jaupart C, Mareschal JC (2014) Constraints on crustal heat production from heat flow data. In: Rudnick RL (ed) Treatise on geochemistry (Second Edition), The Crust, vol 4. Elsevier, Amsterdam, pp 53-73

Jelen B, Rifelj H (2003) The Karpatian in Slovenia. In: Brzobohatý R, Cicha I, Kovač M, Rögl F (eds) The Karpatian. A lower miocene stage of the Central Paratethys. Masaryk University Brno, Brno, pp 133-139

Jelen B, Rifelj H (2005) On the dynamics of the Paratethys Sedimentary Area in Slovenia. In: 7th workshop on Alpine geological Studies, Abstract Book, 45-46, Croatian Geological Society, Zagreb

Kappelmeyer O, Haenel R (1974) Geothermics with special reference to application. Geoexploration Monographs, series 1, No 4., Gebrüder Borntraeger, Berlin, Stuttgart, p 238

Kiss J (2005) A CELEBRATION-7 szelvény komplex geofizikai vizsgálata, és a „sebesség-anomália” fogalma. Magyar Geofizika 46:1-10

Koulakov I, Kaban MK, Tesauro M, Cloetingh S (2009) P- and S-velocity anomalies in the upper mantle beneath Europe from tomographic inversion of ISC data. Geophys J Int 179:345-366

Kovač M, Baráth I, Harzhauser M, Hlavatý I, Hudáčková N (2004) Miocene depositional systems and sequence stratigraphy of the Vienna Basin. Cour Forsch Inst Senckenberg 246:187-212

Kovács I, Falus Gy, Stuart G, Hidas K, Szabó Cs, Flower MFJ, Hegedűs E, Posgay K, Zilahi-Sebess L (2012) Seismic anisotropy and deformation patterns in upper mantle xenoliths from the central Carpathian-Pannonian region: Asthenospheric flow as a driving force for Cenozoic extension and extrusion? Tectonophysics 514-517:168-179

Kraljić M et al (2005) Poročilo o izgradnji vrtine Benedikt-2 (Be-2). Technical report, Nafta Geoterm, Lendava

Lankreijer A, Kovác M, Cloetingh S, Pitosák P, Hloska M, Biermann C (1995) Quantitative subsidence analysis and forward modelling of the Vienna and Danube basins: thin-skinned versus thick-skinned extension. Tectonophysics 252:433-451

Lankreijer A, Bielik M, Cloetingh S, Majcin D (1999) Rheology predictions across the western Carpathians, Bohemian massif and the Pannonian basin: Implications for tectonic scenarios. Tectonics 18:1139-1153 
Lenkey L (1999) Geothermics of the Pannonian basin and its bearing on the tectonics of basin evolution. $\mathrm{PhD}$ thesis, Vrije Universiteit, Amsterdam, p 215

Lenkey L, Dövényi P, Horváth F, Cloetingh S (2002) Geothermics of the Pannonian basin and its bearing on the neotectonics. EGU Stephan Mueller Spec Publ Ser 3:29-40

Magyar I, Geary DH, Müller P (1999) Paleogeographic evolution of the Late Miocene Lake Pannon in Central Europe. Palaeogeogr Palaeoclimatol Palaeoecol 147:151-167

Magyar I, Radivojević D, Sztanó O, Synak R, Ujszászi K, Pócsik M (2013) Progradation of the paleoDanubeshelf margin across the Pannonian Basin during the Late Miocene and Early Pliocene. Global Planet Change 103:168-173

Majorowicz J, Wybraniec S (2011) New terrestrial heat flow map of Europe after regional paleoclimatic correction application. Int J Earth Sci 100:881-887. doi:10.1007/s00531-010-0526-1

Maros Gy (2012) In: Maros GY, Albert G, Barczikayné Szeiler R, Fodor L, Gyalog L, Jocha-Edelényi E, Kercsmár ZS, Magyari Á, Maigut V, Nádor A, Orosz L, Palotás K, Selmeczi I, Uhrin A, Vikor ZS, Atzenhofer B, Berka R, Bottig M, Brüstle A, Hörfarter C, Schubert G, Weilbold J, Baráth I, Fordinál K, Kronome B, Maglay J, Nagy A, Jelen B, Lapanje A, Rifelj H, Rižnar I, Trajanova M (eds) Summary report of geological models. TransEnergy

Matenco L, Radivojević D (2012) On the formation and evolution of the Pannonian Basin: constraints derived from the structure of the junction area between the Carpathians and the Dinarides. Tectonics. doi:10.1029/2012TC003206

McKenzie D (1978) Some remarks on the development of sedimentary basins. Earth Planet Sci Lett 40:25-32

Mitterbauer U, Behm M, Brückl E, Lippitsch R (2010) ALPASS- Neue Erkenntnisse über die seismische Struktur des oberen Erdmantels in den Ostalpen, Pangeo 2010, 15.9.-19.9.2010, Leoben

Rajver D, Ravnik D (2002) Geothermal pattern of Slovenia-enlarged database and improved geothermal maps (in Slovene). Geologija 45:519-524. doi:10.5474/geologija.2002.058

Ratschbacher L, Merle O, Davy Ph, Cobbold P (1991a) Lateral extrusion in the Eastern Alps. Part 1: Boundary conditions and experiments scaled for gravity. Tectonics 10:245-256

Ratschbacher L, Frisch W, Linzer HG, Merle O (1991b) Lateral extrusion in the Eastern Alps. Part 2: Structural analysis. Tectonics 10:257-271

Ravnik D (1991) Geotermične raziskave v Sloveniji; Geothermal investigations in Slovenia. Geologija 34:265-303 (in Slovenian, with English summary)

Ravnik D, Rajver D, Poljak M, Živčić M (1995) Overview of the geothermal field of Slovenia in the area between the Alps, the Dinarides and the Pannonian basin. Tectonophysics 250:135-149

Rman N, Gál N, Marcin D, Weilbold J, Schubert G, Lapanje A, Rajver D, Benková K, Nádor A (2015) Potentials of transboundary thermal water resources in the western part of the Pannonian basin. Geothermics 55:88-98

Royden LH (1985) The Vienna basin: a thin-skinned pull-apart basin. In: Biddle KT, Christie-Blick N (eds) Strike-slip deformation, basin formation, and sedimentation: Society of Economic Paleontologists and Mineralogists, vol 37. Special Publication, Tulsa, pp 319-338

Royden LH, Dövényi P (1988) Variations in extensional styles at depth across the Pannonian basin system. In: Royden LH, Horváth F (eds) The Pannonian Basin, a study in basin evolution, vol 45. Amer. Assoc. Petr. Geol. Mem, Tulsa, pp 235-255

Royden L, Keen CE (1980) Rifting process and thermal evolution of the continental margin of Eastern Canada determined from subsidence curves. Earth Planet Sci Lett 51:343-361

Royden LH, Horváth F, Rumpler J (1983a) Evolution of the Pannonian basin system: 1. Tectonics. Tectonics 2:63-90

Royden LH, Horváth F, Nagymarosy A, Stegena L (1983b) Evolution of the Pannonian basin system: 2. Subsidence and thermal history. Tectonics 2:91-137

Sachsenhofer RF, Lankreijer A, Cloetingh S, Ebner F (1997) Subsidence analysis and quantitative basin modelling in the Styrian Basin (Pannonian Basin System, Austria). Tectonophysics 272:175-196

Šafanda J, Rajver D (2001) Signature of the last ice age in the present subsurface temperatures in the Czech Republic and Slovenia. Global Planet Change 29:241-257

Scarascia S, Cassinis R (1997) Crustal structure in the central-eastern Alpine sector: a revision of the available DSS data. Tectonophysics 271:157-188

Schmid SM, Bernoulli D, Fügenschuh B, Matenco L, Schefer S, Schuster R, Tischler M, Ustaszewski K (2008) The Alpine-Carpathian-sDinaric orogenic system: correlation and evolution of tectonic units. Swiss J Geosci 101:139-183

Sclater JG, Royden L, Horváth F, Burchfiel BC, Sempken S, Stegena L (1980) The formation of the intraCarpathian basins as determined from subsidence data. Earth Planet Sci Lett 51:139-162 
Sroda P (2006) Seismic anisotropy of the upper crust in southeastern Poland-effect of the compressional deformation at the EEC margin: results of CELEBRATION 2000 seismic data inversion. Geophys Res Lett 33:L22302. doi:10.1029/2006GL027701

Stüwe K (2002) Geodynamics of the Lithosphere. Springer, New York, pp 1-348

Szafián P, Tari G, Horváth F, Cloetingh S (1999) Crustal structure of the Alpine-Pannonian transition zone: a combined seismic and gravity study. Int J Earth Sci 88:98-110

Szanyi J, Kovács B (2010) Utilization of geothermal systems in South-East Hungary. Geothermics 39:357-364

Tari G, Horváth F (2010) Eo-alpine evolution of the Transdanubian Range in the nappe system of the Eastern Alps: Revival of a 15 years old tectonic model. (A Dunántúli-középhegység helyzete és eoalpi fejlődéstörténete a keleti-Alpok takarós rendszerében: Egy másfél évtizedes tektonikai modell időszerüsége.) Földtani Közlöny, 140, 483-510

Tari G, Horváth F, Rumpler J (1992) Styles of extension in the Pannonian Basin. Tectonophysics 208:203-219

Tomek C, Dvoráková L, Ibrmajer I, Jiricek R, Koráb T (1987) Crustal profiles of active continental collisional belt: Czechoslovak deep seismic reflection profiling in the West Carpathians. Geophys J R Astr Soc 89:383-388

Tóth G, Rman N, Rotár-Szalkai Á, Kerékgyártó T, Szőcs T, Lapanje A, Černák R, Remsík A, Schubert G, Nádor A (2016) Transboundary fresh and thermal groundwater flows in the west part of the Pannonian Basin. Renew Sustain Energy Rev 57:439-454

Wessely G (1988) Structure and development of the Vienna Basin in Austria. In: Royden LH, Horváth F (eds) The Pannonian Basin, a study in basin evolution, vol 45. Amer. Assoc. Petr. Geol. Mem, Tulsa, pp 333-346

Yan QZ, Mechie J (1989) A fine structural section through the crust and lower lithosphere along the axial region of the Alps. Geophys J 98:465-488

Zoth G, Haenel R (1988) Appendix. In: Haenel R, Rybach L, Stegena L (eds) Handbook of terrestrial heatflow determination with guidelines and recommendations of the International Heat Flow Commission. Kluwer Academic Publishers, Dordrecht, pp 449-466 